\title{
Mitigation of ancient coal mining hazards to overhead line equipment structures
}

Aliasger E. Haiderali PhD, CEng, MICE

Consultant, Network Rail, Manchester, UK (aliasger.haiderali@gmail.com) (Orcid:0000-0002-7742-881X)

Subsidence and collapse of structures supporting overhead line equipment (OLE) due to legacy coal mining can be catastrophic during both the construction and operational phases, causing damage to construction plant, injuries and fatalities to the construction and maintenance workforce, failure of the track and disruption to the operational railway. When applied to linear railway schemes spanning considerable distances, industry guidelines for appraising and mitigating these mining hazards are overly conservative with a disproportionate cost. On phase 4 of the North West Electrification Project between Manchester Victoria and Euxton Junction, an innovative risk-based method was devised and implemented to identify and mitigate mining hazards to OLE structures. Formulation of these valueengineering solutions prevented programme drift and led to significant cost savings. Details of this methodology, including a detailed desk study, computational geomechanics, a well-targeted ground investigation, void remediation and real-time foundation monitoring, are discussed in this paper.

\author{
Notation \\ $B \quad$ bulking factor \\ $c \quad$ subsidence radius of influence from collapsed shaft \\ $D_{\mathrm{c}} \quad$ height of void migration \\ $\boldsymbol{H} \quad$ shear force at pile head \\ $h \quad$ thickness of worked seam \\ $\boldsymbol{M} \quad$ overturning moment at pile head \\ $R \quad$ rock cover \\ $\boldsymbol{V} \quad$ axial load on pile \\ $z \quad$ thickness of superficial deposits \\ $\theta \quad$ angle of subsidence \\ $\phi \quad$ angle of internal friction
}

\section{Introduction}

As part of phase 4 of the North West Electrification Project (NWEP), the route between Manchester Victoria and Euxton Junction (Figure 1) is proposed for overhead line electrification. Approximately $40 \mathrm{~km}$ in length, the route is part of the Manchester-to-Preston line, which is one of the busiest railway lines in north-west England. It is widely used by commuters and connects key stations such as Bolton, Lostock, Horwich Parkway, Blackrod, Chorley and Buckshaw Parkway to Manchester Victoria. It interfaces with already electrified lines at Euxton Junction, Deal Street Junction and Ordsall Lane Junction.

The installation of $25 \mathrm{kV}$ AC overhead line equipment (OLE) and auto-transformer feeder cables in conjunction with line speed improvement works, track realignment and renewal, signalling and telecommunication alterations, the replacement of level crossings with footbridges, Bolton station remodelling and overbridge reconstructions along this route will enable an increase in the frequency of train services between Manchester Victoria and Preston. Furthermore, compared with trains running on diesel fuel, electric trains are environmentally superior due to their quieter operation and $20-30 \%$ less carbon dioxide emissions per passenger mile.

A key project challenge was the presence of ancient shallow coal workings and shafts beneath or in close proximity to the railway corridor. Mining-induced ground subsidence can be catastrophic during both the construction and operation of OLE structures, causing damage to construction equipment, injuries and fatalities to the construction and maintenance workforce, destabilisation of the track and disruption to the operation of the railway. The innovative methodology used in the identification, appraisal and mitigation of these hazards is the focus of this paper.

\section{OLE foundations}

OLE foundations are subject to loads from the self-weight of the structure and the OLE, wind, ice, construction and maintenance activities, temperature effects and tension in the conductor (BSI, 2013). The lateral shear force and overturning moment govern their analysis and design.

The majority of these foundations are designed using the empirical UIC-ORE method (UIC-ORE, 1957) due to the ease with which the foundation type, size and embedment depth can be determined from design tables using simply the ground topography and overturning moment. This method was formulated on the basis of a large number of full-scale static load tests and is therefore compliant to BS EN 1997-1 (BSI, 2004). The standardised foundation types, in order of preference, are $610 \mathrm{~mm}$ and $724 \mathrm{~mm}$ dia. open-ended tubular steel piles, $750 \mathrm{~mm}$ and $1000 \mathrm{~mm}$ dia. bored piles and reinforced concrete pad footings (e.g. $6 \mathrm{~m}$ long and $2.5 \mathrm{~m}$ wide). In addition to being inefficient in resisting lateral loads, the use of pad footings is limited due to topography and space constraints on the railway. 


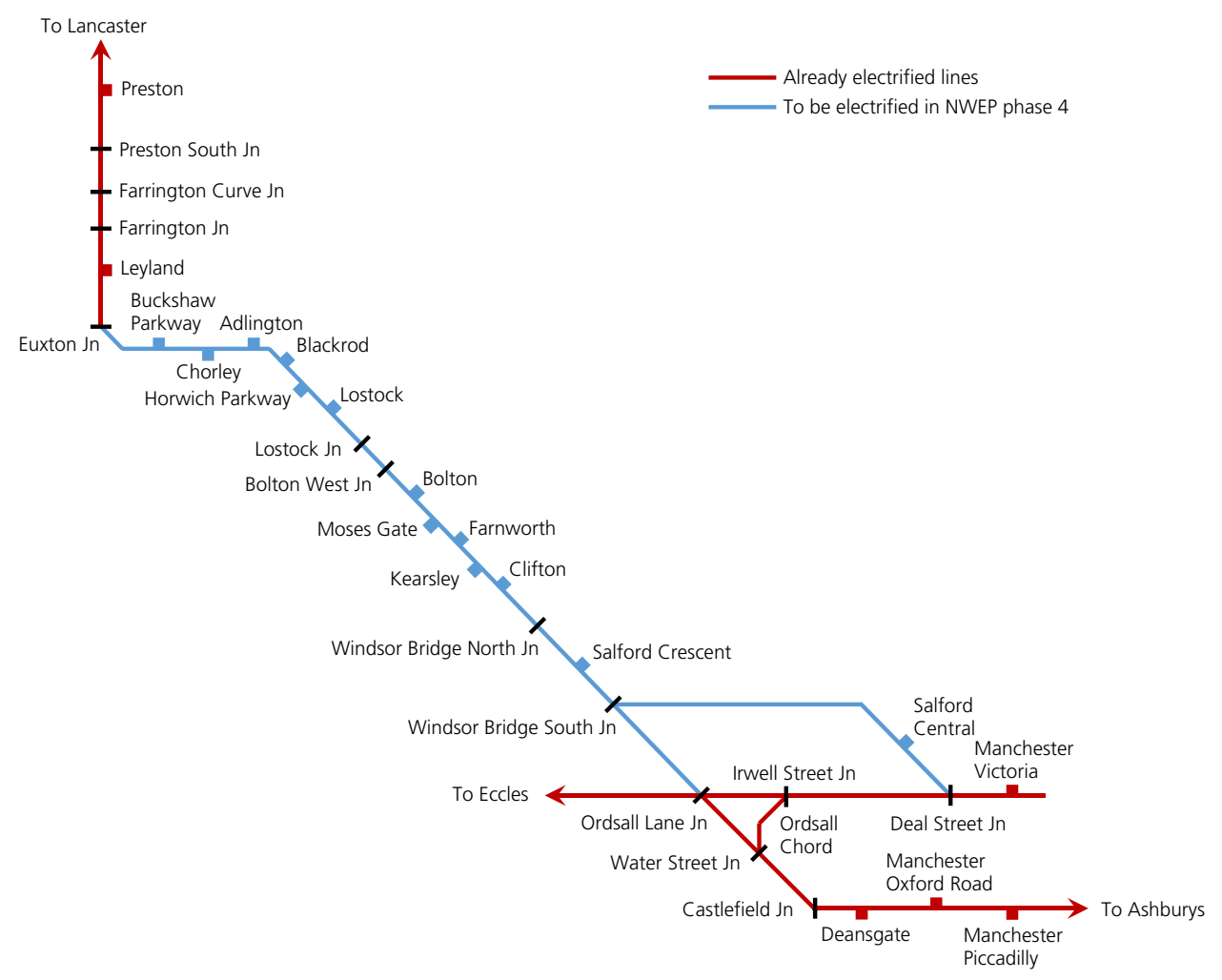

Figure 1. Schematic illustration of the route for NWEP phase 4

Soft compressible soils, poor earthworks and excessive loads are conditions that dictate the use of the more rigorous calculation approach of BS EN 1997-1 (BSI, 2004) for foundation design. Even though the same standard foundation types are usually used, use of this bespoke design method results in deeper piles and larger pad footings relative to the UIC-ORE method. In areas with a mining legacy, either design method could be used pending the outcome of a mining investigation. However, the UIC-ORE method is preferred due to the simplified design process and smaller foundations.

There was a project requirement for approximately 1750 foundations to support various structure types including single-track cantilevers, twin-track cantilevers (Figure 2), two-track portal gantries, four-track portal gantries, twin cantilevered masts, self-supporting anchors, mid-point anchor portal gantries and anchor ties. Of these foundations, 1477 were in mining-affected areas.

\section{Coal mining}

Extensive coal mining took place in north-west England from the beginning of the industrial revolution in the early nineteenth century to the last quarter of the twentieth century. Most of the NWEP phase 4 route has bedrock geology comprising the coal-bearing Pennine Coal Measures Group formed during the Carboniferous period and divisible into lower, middle and upper formations. The Coal Measures formations occur at relatively shallow depths and comprise sequences of seatearth, coal, mudstone, siltstone and sandstone beds. They are interspersed with the Openshaw Sandstone, Worsley Delf Rock, Newton Heath Sandstone, Peel Hall Rock, Trencherbone Rock, Cannel Rock, Old Lawrence Rock, Milnrow Sandstone, Helpet Edge Rock, Great Arc Sandstone and Ousel Nest Grit formations. The bedrock is overlain by Quaternary superficial deposits comprising glacial till, glaciofluvial ice-contact deposits, glaciofluvial sheet deposits, glaciolacustrine deltaic deposits, hummocky glacial deposits, river terrace deposits and alluvium (BGS, 2017). Coal mining hazards were discounted for sections at either end of the route, totalling $4.3 \mathrm{~km}$, due to the coal-bearing strata being much deeper and overlain by the Chester Formation and Sherwood Sandstone Group formed during the more recent Triassic and Permian periods.

The earliest open-cast coal mines from the thirteenth and fourteenth centuries consisted of drifts and adits into shallow seams at the base of quarries, open pits or along outcrops in hills, and bell pits whose shafts rarely exceeded a depth of $12 \mathrm{~m}$. Where a coal seam was at a depth greater than $7 \mathrm{~m}$ from the surface, headings that radiated into the coal seam for short distances around the shaft were usually used instead of bell pits (Bell et al., 1988). Increased demand for coal in the 


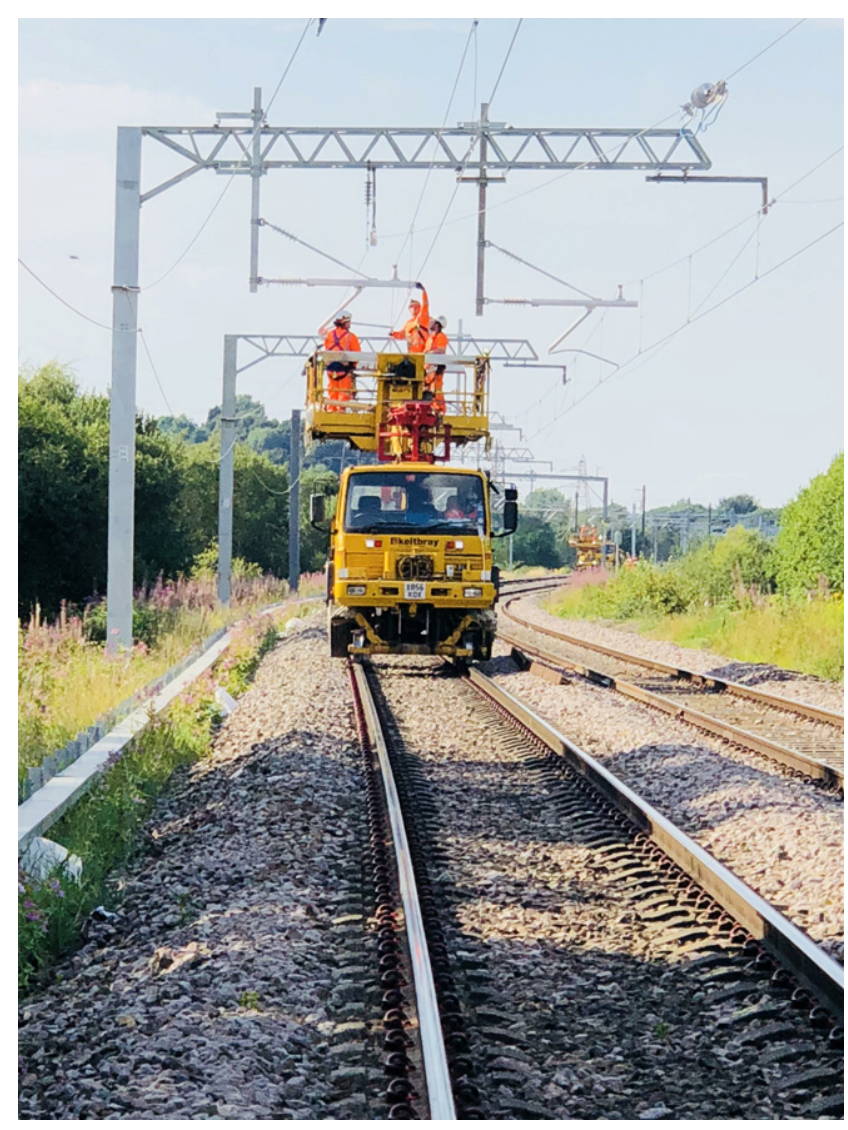

Figure 2. OLE twin-track cantilevers undergoing wiring (courtesy of Keltbray)

sixteenth century led to the development of the pillar-and-stall method of extraction (also known as room and pillar), which consisted of a network of interconnecting chambers with pillars of rock left to support the roof of the mine. Workings extended a maximum of $200 \mathrm{~m}$ from the shaft, whose depth was limited to $60 \mathrm{~m}$. The onset of the industrial revolution in the eighteenth century and the corresponding demand for large amounts of coal led to the use of the longwall method of deep mining. This involved the extraction of the entire coal seam in a long underground face with the roof support withdrawn from behind the protected working face, allowing controlled subsidence of the worked area. According to Healy and Head (1984), ground subsidence due to longwall mining does not pose a serious risk to structural stability.

Coal extractions to a maximum depth of $30 \mathrm{~m}$ below the ground surface are termed shallow workings (Coal Authority, 2017). Shallow workings pose the risk of subsidence, defined as the time-dependent deformation of the ground surface caused by the rearrangement of the overburden above voids. As the rock overlying the shallow working becomes unstable and gradually collapses into the cavity, the combined influence of gravity and weathering causes the void to propagate towards the surface. Due to bulking of the collapsed rock, migration of the void would be eventually halted but at shallow depths it can reach the surface and cause abrupt depressions. Upward void migration can also be arrested by a strong competent bed of rock acting as a beam spanning the void. Factors that influence the extent of void migration include the width of the unsupported cavity or stall, the nature of the overlying rocks, the thickness and dip of the seam, the depth of overburden and the groundwater regime (Bell et al., 1988).

Loads imposed by structures can gradually weaken the roof of shallow mine workings and cause eventual collapse and subsidence. This is particularly a problem for pillar-and-stall workings, as opposed to deep mining, since the overburden pressure at shallow depths is not high enough to cause the roof supports to collapse immediately after extraction.

Failure of an abandoned shaft caused by settlement/collapse of the infill material or failure of the staging leads to voids that travel up the shaft and manifest in the formation of a sudden sinkhole. As shown in Figure 3, Bell (1978) found that such a sinkhole would extend radially from the shaft by the dimension $c$, computed using

\section{1. $c=z \tan \theta$}

where $z$ is the thickness of superficial deposits and $\theta$ is the angle of subsidence, which is the complement of the angle of internal friction $(\phi)$ of the superficial deposits.

Where a shaft has been left open beneath the staging, deterioration of the lining causes movement of unconsolidated overburden below the staging, leading to surface instabilities (Healy and Head, 1984).

Various approximations have been suggested to estimate the height above a worked seam to which voids may migrate. Walton and Cobb (1984) proposed that void migration is limited to three times the width of the stall, whereas Piggott

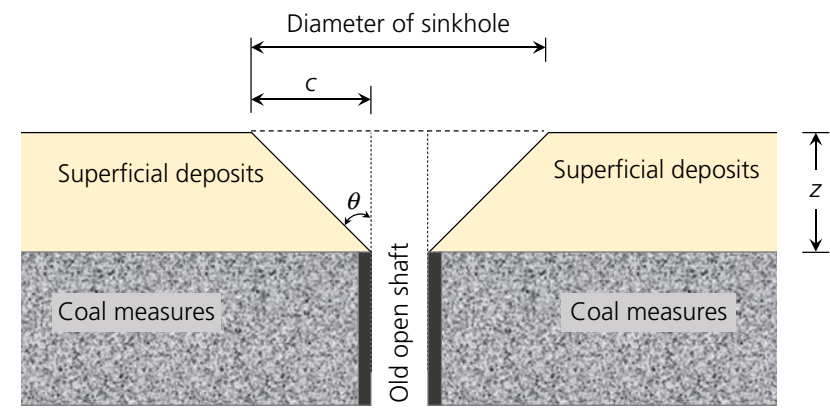

Figure 3. Sinkhole subsidence due to shaft failure (adapted from Bell (1978)) 
and Eynon (1978) recommended a value of 1.75. However, due to difficulties in obtaining stall dimensions of abandoned workings, the concept of relating the height of void migration to the worked seam thickness, derived by Piggott and Eynon (1978), is preferred instead. As illustrated in Figure 4, they theorised that the void adopted either a conical, wedge or rectangular form of collapse and that the height of void migration $\left(D_{\mathrm{c}}\right)$ was a function of the worked seam thickness $(h)$ and the bulking factor of the overlying strata $(B)$. For Coal Measures, the value of $B$-defined as the change in volume of material from the unbroken to the broken state - typically varies between 30 and 50\%. Piggott and Eynon concluded that hazardous conditions existed where old mine workings occurred at depths less than ten times the worked seam thickness below the bedrock surface. According to Bell et al. (1988), the height of void migration was generally between three and five times the thickness of the worked seam and would only extend to ten times the seam thickness under exceptional circumstances. However, as pointed out by Healy and Head (1984), these theories are contentious and not suitably substantiated.

In the construction industry, the findings of Piggott and Eynon (1978) underpin mining investigations whereby a rock cover-to-seam thickness ratio $(R / h)$ of ten is adopted as the minimum acceptable threshold that would prevent ground subsidence. Remedial works, including intrusive mining investigations, are carried out at locations where this criterion is not satisfied. Superficial deposits and made ground are omitted when working out the available cover to the worked seam as they are characterised by low values of $B$.

\section{Methodology}

Intrusive mining surveys on a linear railway project spanning a considerable distance are complex to organise, expensive and time-consuming. Due to 'rules of the route' possessions being very short $(4-5 \mathrm{~h})$, multiple shifts are usually required to undertake a single borehole on the railway lineside, making this a very

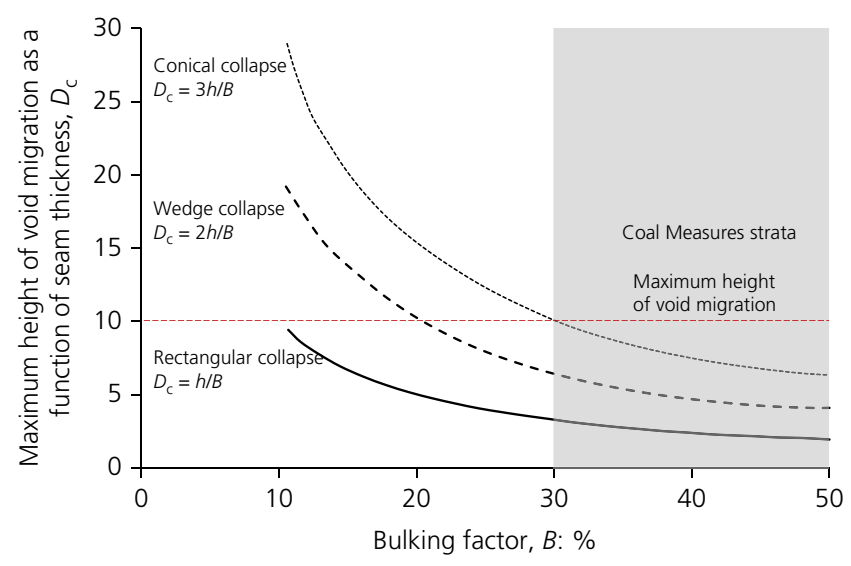

Figure 4. Height of void migration for various void forms (adapted from Piggott and Eynon (1978)) expensive activity. There are also additional costs for road rail vehicles and safety-critical staff to be considered.

On previous electrification schemes affected by the coal mining legacy, mining investigations were extensive in scope, cost and programme. It had been common practice to undertake a borehole at every foundation location at which the $R / h$ ratio was judged to be less than ten. For instance, on NWEP phase $2 \mathrm{~b}$, more than 100 rotary boreholes were undertaken along the $20 \mathrm{~km}$ route between Huyton and Wigan. Likewise, on the Rugeley Trent Valley-to-Walsall project, £2.5 million was spent on boreholes, with $£ 9$ million of associated delay damages incurred (Project Stakeholders, 2017).

Due to budgetary and programme constraints on NWEP phase 4, an innovative approach that deviated significantly from that used on previous projects was adopted to mitigate the risks from coal mining hazards. The procedure was developed by Network Rail in-house and implemented on-site by its OLE design-and-build contractor.

\subsection{Mining desk study}

The first step involved carrying out a detailed mining desk study for each foundation location along the route. The desk study was used to obtain information on

ground topography

- the estimated thickness of coal seams/extraction thickness

- the rock cover to the coal seams

- coal seam contours

- the type and estimated thickness of superficial deposits

- bedrock geology

- dip orientation and fault geometry

- conjectured locations of shafts and their distance from the proposed foundation positions

- coal seams at risk of spontaneous combustion

- groundwater levels and

- the extraction thickness of other Coal Measures deposits such as fireclay.

Due to the made ground at embankments providing increased overburden over any potential shallow mine workings and shafts, greater importance was placed on cutting and at-grade locations.

Information was compiled from an extensive list of sources, including

- British Geological Society (BGS) 1:50 000 and 1:63 360 geological maps and memoirs

- BGS Geoindex borehole records

- the BGS advanced superficial thickness model

- boreholes for civil and structural engineering schemes in NWEP phase 4 and other projects

- cab-ride video footage

- Network Rail earthwork condition reports 
Transport

Volume 173 Issue 4
Mitigation of ancient coal mining hazards to overhead line equipment structures

Haiderali current and historical Ordnance Survey maps

- Coal Authority abandonment plans and the interactive map viewer and

- the Network Rail mining index database.

An extract from the desk study, illustrating the bedrock geology, faults and coal seams along the route between Moses Gate and Bolton, is shown in Figure 5.

The desk study indicated that the rock cover exceeded ten times the extraction thickness of shallow workings at 1207 locations of the proposed foundations. At these locations, the contractor was permitted to use $610 \mathrm{~mm} / 724 \mathrm{~mm}$ driven steel piles without any restrictions. However, 255 locations where this criterion was not satisfied were also identified. If the project had followed the precedent of carrying out an intrusive mining survey at each of these locations, it would have necessitated more than 200 boreholes, which was not a realistic proposition due to the impact on cost and programme. Instead, an alternative approach utilising finite-element (FE) modelling and real-time foundation monitoring was implemented.

\subsection{FE modelling}

Compared with other analytical and numerical techniques, the FE method has proven to be a powerful tool in the

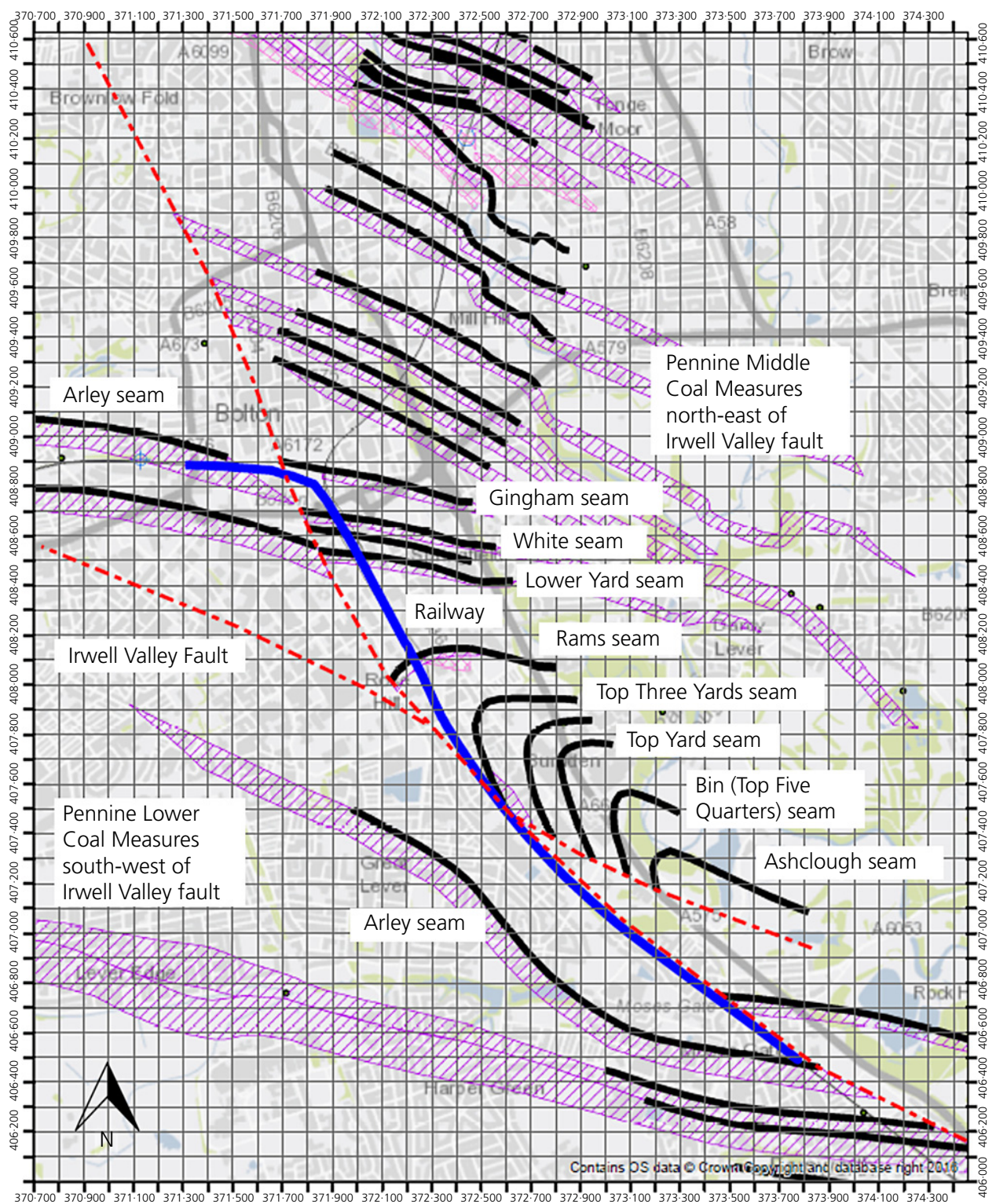

Figure 5. Bedrock geology, faults and coal seams between Moses Gate and Bolton. (c) Crown copyright 2019 Ordnance Survey. Media 038/19 
prediction of mining subsidence (Najjar and Zaman, 1994; Sepehri et al., 2014, 2017). FE modelling has also been used to simulate the dynamic response of OLE structures accounting for train-induced vibrations and soil-structure interaction (Ngamkhanong and Kaewunruen, 2018; Ngamkhanong et al., 2017).

Three-dimensional (3D) FE analyses were carried out using the software Abaqus 2017 (DSSC, 2017) to predict the axial and lateral behaviour of a bored pile in the presence of a void. Bored piles were used in the simulations as they presented a much lower risk of soil disturbance during construction in comparison with pile driving. Non-linearity of the soil resistance around a laterally loaded pile and the complex stresses induced around the void required 3D modelling.

In accordance with the design approach outlined in BS EN 50119+A1 (BSI, 2013), it was assumed that the railway track bed and earthworks would provide a satisfactory load path for dynamic train loading to be distributed to the subgrade without imposing a significant surcharge load on the OLE foundation. In addition, Network Rail had a separate nationwide project to evaluate and remediate mining hazards to the track. Hence, the railway track was excluded from these analyses.

A series of analyses, representative of the pile geometry and ground conditions at the aforementioned locations, was undertaken. The geometry and sequence of the superficial soils and Coal Measures were based on the desk study whereas available factual geotechnical information (windowless samples, superheavy dynamic probes, rotary cores and in situ and laboratory tests on soils and rocks) for design schemes in the vicinity of the proposed OLE structures, well-established empirical correlations and published literature were used to determine conservative material properties.
The soils and Coal Measures were analysed as fully saturated porous media using the poroelastoplasticity formulation, which couples the deformation of a porous medium and transient pore fluid flow (Biot, 1941). The constitutive models employed included the Mohr-Coulomb model with a non-associative flow rule, the Modified Cam Clay model and the concrete damage plasticity model. For the Coal Measures, the geotechnical parameters satisfied the Hoek-Brown model but were then converted to equivalent values of cohesion and angle of shearing resistance for use with the Mohr-Coulomb failure criterion in Abaqus.

At the preliminary modelling stage, a study was undertaken to verify the effect on the results of varying sensitive material properties such as stiffness, undrained shear strength, cohesion, angle of shearing resistance and interface friction angle, with necessary adjustments made to ensure that a safe, lower-bound solution was obtained (Table 1). Concrete was assigned a density of $2400 \mathrm{~kg} / \mathrm{m}^{3}$, a Poisson's ratio of $0 \cdot 19$, Young's modulus of $19 \cdot 7 \mathrm{GPa}$ and a dilation angle of $38^{\circ}$.

Geomechanical parameters such as model dimensions, element type and size, viscous damping, limiting interface shear stress and contact discretisation, tracking and enforcement algorithms were also carefully selected.

The vertical model boundary was positioned at a radius of ten times the pile diameter and its base at a minimum distance of $10 \mathrm{~m}$ from the underside of the void to minimise artificial boundary effects on the stress-deformation behaviour of the pile-ground system. The base was fixed against translation in all directions whereas the vertical boundary was fixed against horizontal translation. Hydraulically, the ground surface was a drained boundary while the vertical boundary and the base were impermeable.

Table 1. Sensitive material properties

\begin{tabular}{|c|c|c|c|c|c|}
\hline Material & $\begin{array}{l}\text { Undrained shear } \\
\text { strength: kPa }\end{array}$ & $\begin{array}{l}\text { Cohesion: } \\
\text { kPa }\end{array}$ & $\begin{array}{l}\text { Angle of shearing } \\
\text { resistance: degrees }\end{array}$ & $\begin{array}{l}\text { Interface angle of } \\
\text { friction: degrees }\end{array}$ & $\begin{array}{l}\text { Stiffness: } \\
\mathrm{MN} / \mathrm{m}^{2}\end{array}$ \\
\hline $\begin{array}{l}\text { Granular made } \\
\text { ground }\end{array}$ & - & - & $25-28$ & $16 \cdot 7-18 \cdot 8$ & $0 \cdot 5-6 \cdot 0$ \\
\hline $\begin{array}{l}\text { Cohesive made } \\
\text { ground }\end{array}$ & $25-40$ & 0 & $21-24$ & $14 \cdot 0-16 \cdot 0$ & $5 \cdot 0-9 \cdot 6$ \\
\hline Loose sand & - & - & 29-31 & $19 \cdot 3-20 \cdot 7$ & $2 \cdot 4-3 \cdot 5$ \\
\hline $\begin{array}{l}\text { Medium dense sand } \\
\text { and gravel }\end{array}$ & - & - & $30-35$ & $20 \cdot 0-23 \cdot 3$ & $3 \cdot 1-20$ \\
\hline Dense sand & - & - & $33-38$ & $22 \cdot 0-25 \cdot 3$ & $16-41 \cdot 2$ \\
\hline Gravel & - & - & $35-38$ & $23 \cdot 3-25 \cdot 3$ & $2 \cdot 5-16 \cdot 1$ \\
\hline Sandy silt & - & - & $30-31$ & $20 \cdot 0-20 \cdot 7$ & $8 \cdot 1-14 \cdot 8$ \\
\hline Soft clay & $25-30$ & 0 & $21-24$ & $14 \cdot 0-16 \cdot 0$ & $5-10 \cdot 8$ \\
\hline Firm to stiff clay & $40-150$ & $0 \cdot 25-5 \cdot 0$ & $24-27$ & $16 \cdot 0-18 \cdot 0$ & $10 \cdot 8-36$ \\
\hline $\begin{array}{l}\text { Stiff to very stiff to } \\
\text { hard clay }\end{array}$ & $75-450$ & $3 \cdot 75-11 \cdot 25$ & $27-29$ & - & 18-90 \\
\hline Coal Measures & - & $15-28$ & $21-40$ & - & $20-55$ \\
\hline
\end{tabular}


Both the pile and the ground were modelled using linear eightnoded brick elements with reduced integration and hourglassing control. Structured, biased meshing ensured a higher mesh density near the pile and the void since these regions were expected to have high stress-strain gradients. A mesh convergence study was undertaken to determine a sufficiently accurate mesh size. Relatively fine meshes with 68472 to 99048 elements were used. An example of a meshed model is shown in Figure 6.

Contact between the pile and the soil was defined using the surface-to-surface contact pair algorithm. The pile, being much stiffer than the soil, was selected as the master surface while the soil in contact with the pile was designated as the slave surface. The relative motion of the two surfaces in the contact pair was tracked using the finite sliding formulation; this is computationally demanding but is more accurate as it permits the contacting surfaces to undergo unlimited sliding and rotation between them.

Contact conditions between the two surfaces were governed by kinematic constraints in the normal and tangential directions. The 'hard' contact pressure overclosure relationship was used to define the normal contact constraints. In the normal direction, the contact stress was zero when a normal gap developed

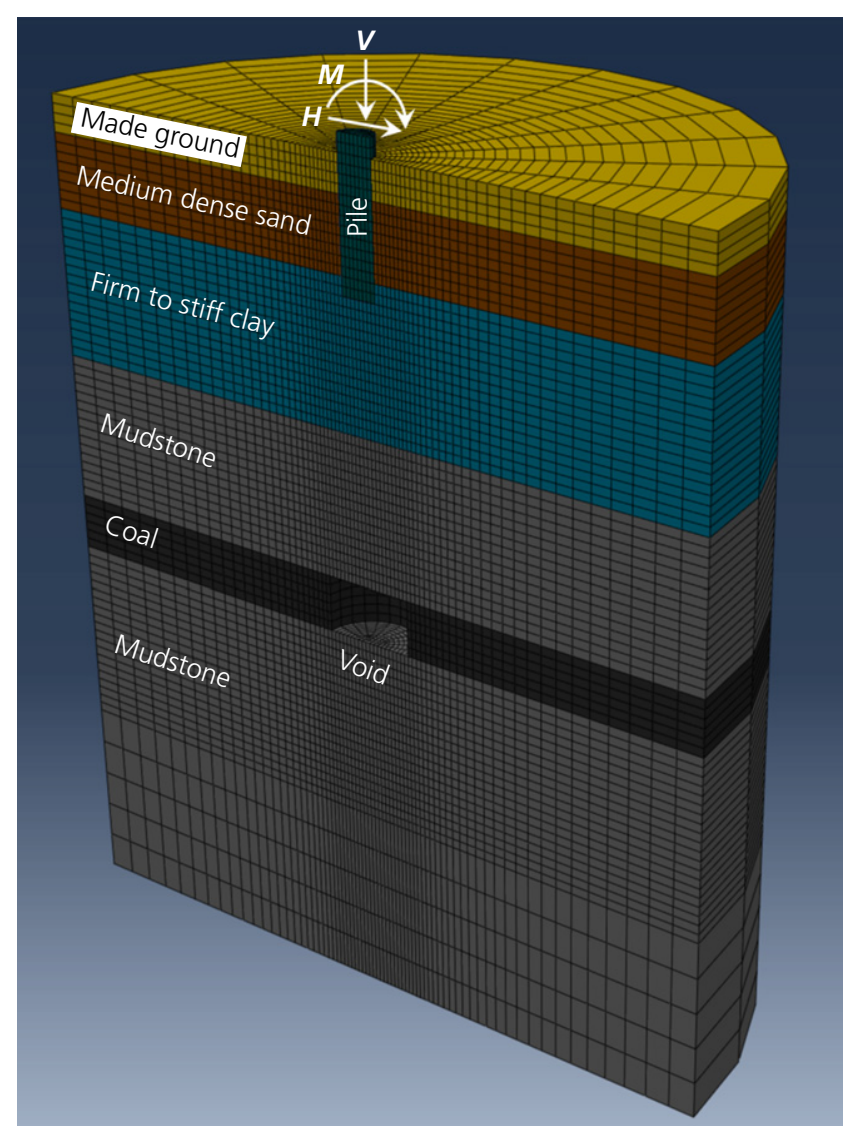

Figure 6. FE model between the two surfaces, or compressive when the two surfaces were in contact. Hence, the transfer of tensile stresses across the interface was prevented.

In the tangential direction, using the Coulomb friction law, the maximum shear stress at the contact was equivalent to the contact stress multiplied by the interface friction coefficient. When the shear stress was less than this critical value, the surfaces were in a state of stick whereas, when it reached the maximum value, the surfaces slid relative to one another in the direction of the shear stress (state of slip). As a conservative measure, the maximum shear stress at the pile-soil interface was limited to the unit shaft friction derived using recommendations given by the American Petroleum Institute (API, 1987) and Naval Facilities Engineering Command (NAVFAC, 1986) for steel piles in order to allow, if required, the use of a permanent casing.

To stabilise the analysis, it was necessary to add a small amount of viscous damping to the model. However, solution accuracy was not compromised by ensuring that the viscous forces were negligible relative to the total forces and that the energy dissipated by viscous damping was a very small proportion of the total internal energy.

The modelled piles were either 0.75 or $1 \mathrm{~m}$ in diameter with embedded lengths varying between 2.75 and $5 \mathrm{~m}$. A cylindrical void, $2.5 \mathrm{~m}$ in diameter and extending throughout the worked coal seam that ranged in thickness between $0 \cdot 8$ and $2 \mathrm{~m}$, was assumed to represent the most onerous field condition when positioned directly underneath the pile. Rock cover-to-seam thickness ratios of $10,5,4,3 \cdot 5,3,2 \cdot 5,2$ and 1 were examined.

After the ground had achieved geostatic equilibrium, the concrete pile was constructed and subjected sequentially to an axial load $\boldsymbol{V}$, a lateral load $\boldsymbol{H}$ and an overturning moment $\boldsymbol{M}$. Maximum characteristic values, derived from OLE detailed designs for over 200 structures, were applied to ensure that the results could be applied to every OLE structure along the route (Table 2). It was interesting to note that the axial load on the concrete pile was less than its self-weight, indicating the OLE structures to be relatively light. This lent credence to the key consideration made when conceptualising these simplified analyses that the proposed OLE infrastructure was in an operational railway that was subjecting the ground to highmagnitude dynamic train loads.

Under lateral loading, the bored pile behaved as a short, rigid pile that deformed by rotating about a distinct pivot point along its embedded length (Figures 7(a) and 7(b)). At contactwire height, which was on average $5.2 \mathrm{~m}$ above ground level, maintenance criteria limited the across-track lateral deflection of an OLE structure under transient loading to $50 \mathrm{~mm}$ (Network Rail, 2015) to minimise the risk of the pantograph losing contact with the contact wire. This limit is a summation 
Table 2. Maximum characteristic foundation loads

\begin{tabular}{lccr|} 
Structure type & V: $\mathbf{k N}$ & H: kN & M: kNm \\
\hline Single-track cantilever & 12 & 8 & 48 \\
Twin-track cantilever & 50 & 36 & 214 \\
Twin cantilevered mast & 25 & 12 & 69 \\
Self-supporting anchor & 50 & 40 & 240 \\
Portal stanchion & 35 & 11 & 66
\end{tabular}

of the deflection of the rigid mast resulting from pile rotation and that caused by the bending of the structure under maximum wind with coexistent temperature. Based on conservative OLE structural design calculations, the maximum deflection at contact-wire height due to bending of the mast was $20 \mathrm{~mm}$, thus restricting the horizontal movement from the rotation of the pile-rigid mast system to $30 \mathrm{~mm}$. The depth along the pile at which the pivot point occurred was calculated from the results of each FE analysis. It varied between $2 \mathrm{~m}$ for the $2.75 \mathrm{~m}$ long pile and $4 \mathrm{~m}$ for the $5 \mathrm{~m}$ long pile. Using these pivot point depths and extending the pile deflection profiles linearly to contact-wire height, the absolute lowest values of the allowable pile tilt and lateral pile deflection at ground level were determined to be $0.19^{\circ}$ and $8.3 \mathrm{~mm}$ respectively
(Figure 7(c)). For simplicity, this deflection criterion was also applied in the along-track direction for structures such as portal gantries and self-supporting anchors instead of using the increased $100 \mathrm{~mm}$ allowance specified in NR/L2/CIV/073 (Network Rail, 2015).

Following discussions with the maintainer, the long-term foundation settlement was limited to $25 \mathrm{~mm}$.

The analyses revealed the effect of the void in bringing about a significant reduction in compressive stress in the ground above and below it. Conversely, there was an increase in compressive stress on the rock pillars either side of the void due to the redistribution of the overburden pressure. This zone of instability, illustrated in Figure 8, propagated upwards in a conical form. Furthermore, the results showed that at $R / h$ ratios of three and higher, the adverse effect of the void on the lateral and vertical deformation of the bored pile was less than $7 \%$ and was therefore concluded to be as low as reasonably practicable, in agreement with the observations made by Bell et al. (1988). Specifically, at $R / h=3$, the maximum envelope values of axial settlement, lateral deflection at ground level and tilt resulting from all these analyses were $6.8 \mathrm{~mm}, 7 \cdot 4 \mathrm{~mm}$

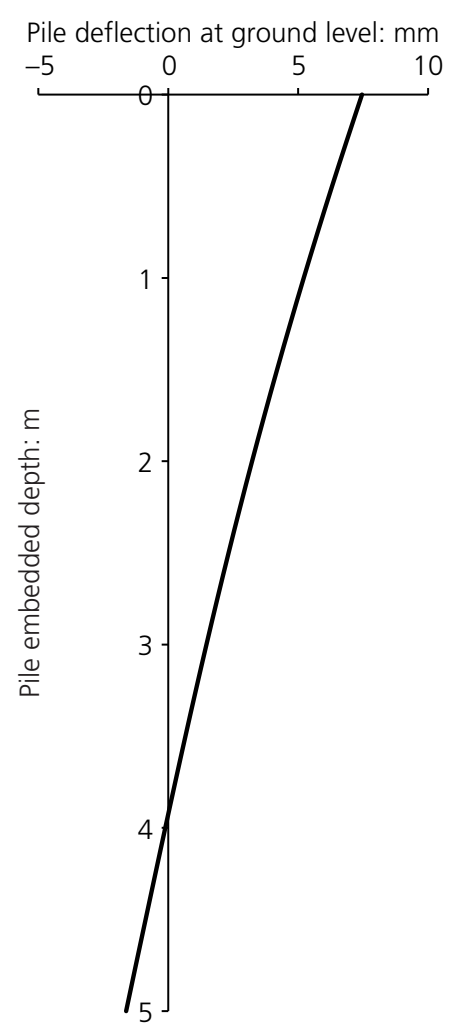

(a)

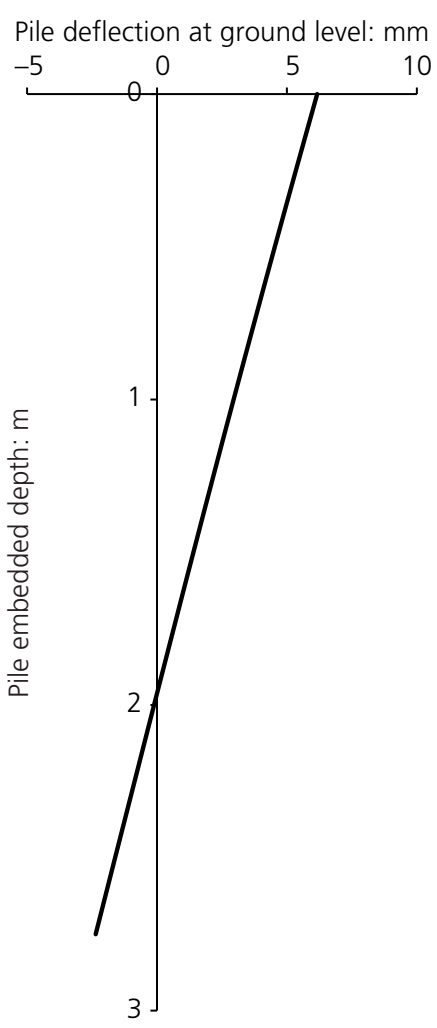

(b)

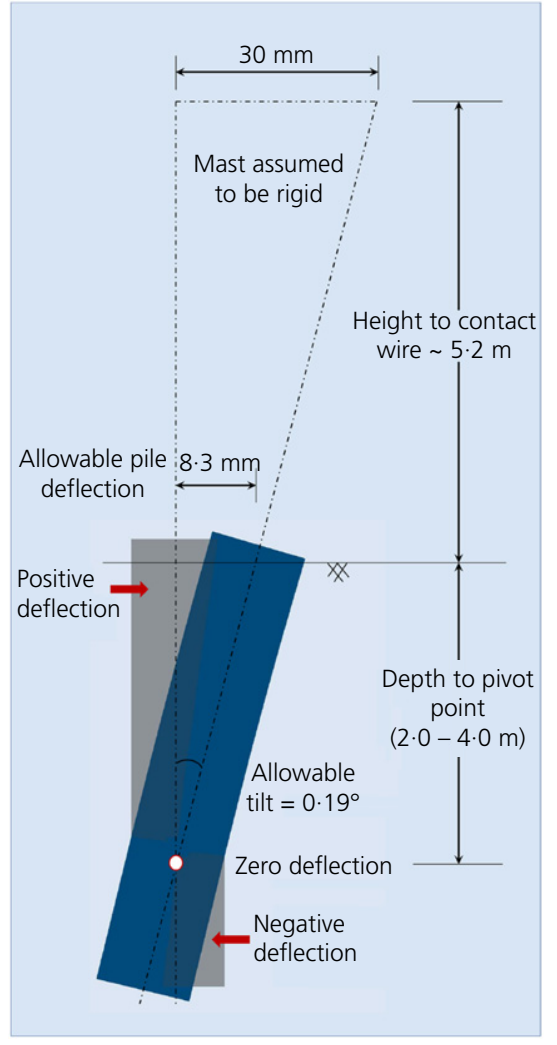

(c)

Figure 7. Lateral pile response: (a) deflection profile of a $2.75 \mathrm{~m}$ long pile; (b) deflection profile of a $5 \mathrm{~m}$ long pile; (c) OLE maintenance limit on structure deflection from rotation of the pile-mast system 
Mitigation of ancient coal mining hazards to overhead line equipment structures Haiderali

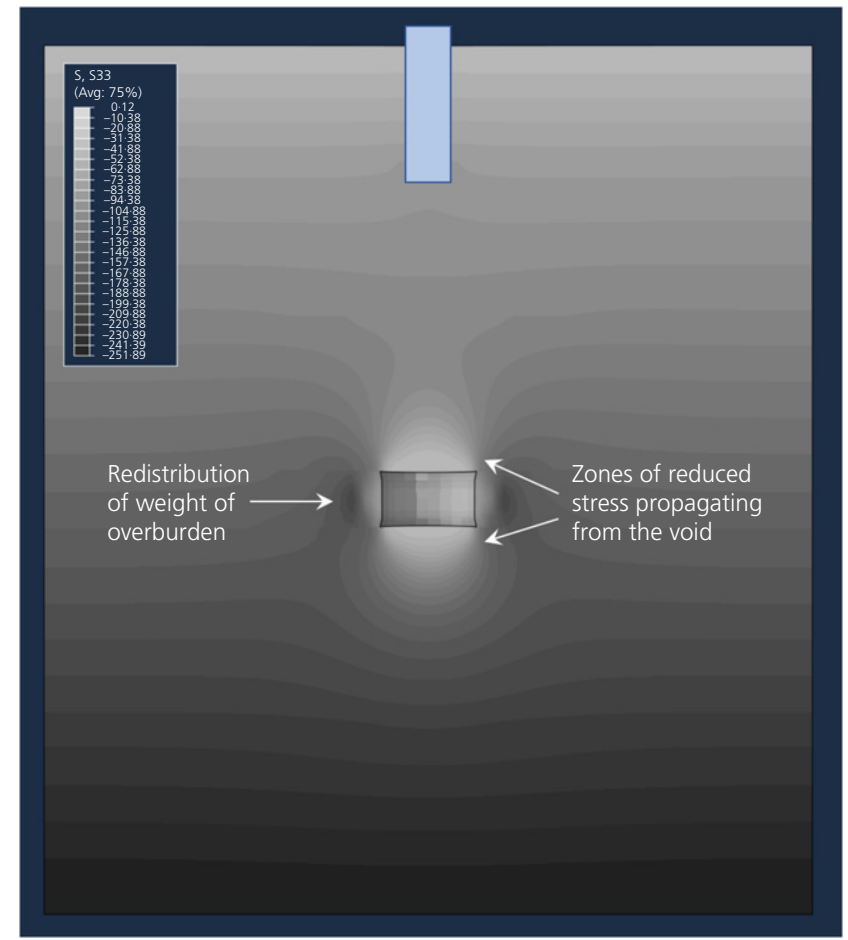

Figure 8. Changes in compressive stress due to a void

and $0.11^{\circ}$ respectively, all within the OLE maintenance limits of $25 \mathrm{~mm}, 8 \cdot 3 \mathrm{~mm}$ and $0 \cdot 19^{\circ}$ respectively.

This led to the formulation of a new rule whereby 171 foundation locations with $R / h$ ratios of between three and ten were prescribed bored piles, obviating the original requirement for an intrusive investigation at these locations. Pad foundations were only used in locations where the thickness of superficial deposits was inadequate to enable the construction of bored piles without having to auger through bedrock.

Reflecting the observations of Carter et al. (1981) that ground subsidence rarely occurs in areas with a substantial amount of overburden, site-specific FE analyses were carried out for a further 35 foundation locations where the overburden exceeded $14 \mathrm{~m}$ but whose $R / h$ ratio was less than three. The results indicated bored piles to perform satisfactorily at these locations too.

Another key benefit derived from the modelling approach was that it enabled the bored piles and pad foundations to be designed using the computationally cheaper UIC-ORE method, which required considerably less design time and availed standardisation efficiencies in construction and procurement of materials.

At several locations, due to the presence of loose sands and gravels, a permanent steel casing, exemplified in Figure 9, was

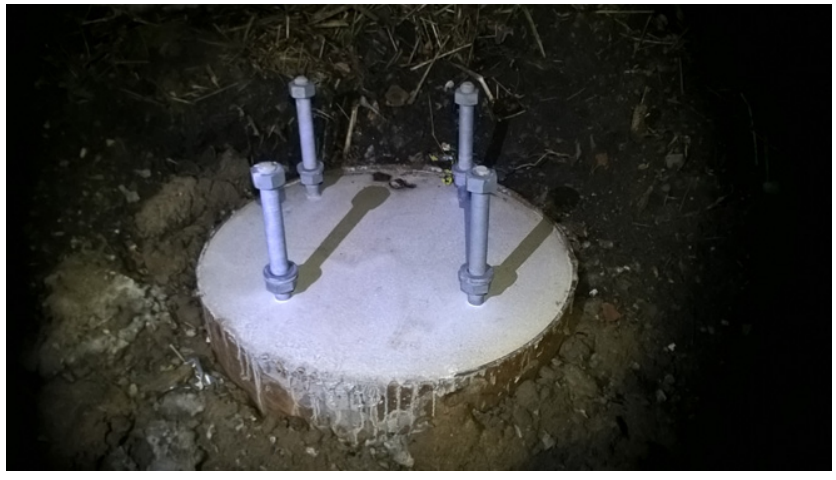

Figure 9. Cased bored pile

installed to stabilise the bore and prevent it from collapsing. Casings were preferred to bentonite slurries due to logistical constraints on transient railway sites hindering the provision of the latter. Wherever possible, the casing was spun into the ground to minimise ground vibrations that could exacerbate mining-related instabilities at these sensitive locations. However, vibratory driving had to be used for casings longer than $3 \mathrm{~m}$ as spinning was ineffective. To reduce the resulting ground vibrations, a high-frequency vibratory driver with a variable eccentric moment was specified. A vibration frequency of $45 \mathrm{~Hz}$ ( $2700 \mathrm{rpm}$ ) was also used to prevent resonance in the soils and bedrock, which would have amplified the ground vibration amplitudes during casing installation.

Verification and calibration of the FE models is currently in progress using foundation monitoring data for improvement and subsequent application to future electrification schemes.

\subsection{Mine shafts}

Initial findings from the desk study showed 23 proposed foundations to be close to estimated positions of abandoned shafts. Due to uncertainties in determining the shaft location accurately and the impracticality of peppering the grid with boreholes, it was assumed that an area within a $10 \mathrm{~m}$ radius of the conjectured shaft location could contain the shaft. The radius of influence of sinkhole subsidence was thence calculated, using Equation 1, from the perimeter of the exclusion area. Of these 23 foundations, three that were inside the exclusion zone were relocated by means of OLE design iterations whereas bored piles were specified for the six foundations that were within the radius of influence. Further reassurance was obtained from a review of track monitoring data, which did not indicate any signs of potential instabilities at these six locations.

Although the use of electrical resistivity tomography was initially contemplated to identify shafts, it was unfeasible due to its susceptibility to railway noise, poor data quality in the presence of ballast and the requirement for vegetation clearance. 


\subsection{Intrusive ground investigation}

Following on from the desk study and computational analyses, an intrusive ground investigation was undertaken in accordance with BS EN 1997-2 (BSI, 2007) at the remaining 28 highrisk locations where the estimated $R / h$ ratio was less than three combined with less than $14 \mathrm{~m}$ overburden.

Since the aim of the investigation was to ascertain the presence of voids rather than to understand the structural details of the bedrock, the more economical rotary open-hole drilling technique (BSI, 2015; BSI, 2016) was used to undertake the boreholes.

The ground investigation also served to verify the accuracy of the desk study. Where there was variance, it was reassuring to note that the desk study findings were conservative.

The depth of the boreholes, correlated to the desk study findings, ranged between 10 and $30 \mathrm{~m}$ at an average cost of $£ 27500$ per borehole (Principal Contractor, Personal communication, 2017). Due to improved drilling rates and logistical issues related to water supply on railway sites, air mist flush was preferred as the drilling fluid except where the Coal Authority permit specifically mandated the use of water flush due to residential dwellings in the vicinity and the possible presence of hazardous gases and coal seams at risk of spontaneous combustion.

Using the percentage of flush returns and fluctuations in the rotational torque of the drill head as indicators of fracturing, voiding and potential instabilities in rock, three locations were identified as having possible voids. At one of these locations, the flush loss was instead attributed to the fractured permeable sandstone overlying the mudstone. At a second location, the thickness of the strong, intact mudstone overlying unstable, broken ground between depths of 23 and $25 \mathrm{~m}$ was considered adequate to arrest any upward void migration. It was thus deemed necessary to remediate only one location, where a void between depths of 9.3 and $9.8 \mathrm{~m}$, collapsed mine workings between depths of 9.8 and $13 \mathrm{~m}$ and insufficient rock cover of $5.2 \mathrm{~m}$ (translating to an $R / h$ ratio of 1.4 ) were identified.

For these 28 locations, bored piles were conservatively specified to lower the risk of ground disturbance.

\subsection{Void remediation}

The remediation scheme, at a cost of around $£ 65000$, involved pressure-injecting $6.6 \mathrm{t}$ of grout to a depth of $15 \mathrm{~m}$ through boreholes at each corner of a $9 \mathrm{~m}^{2}$ square grid at the location of the proposed bored pile. The grid was large enough to prevent differential settlement of the foundation without adversely influencing the track stiffness.

The boreholes terminated $2 \mathrm{~m}$ into intact siltstone beneath the voided rock, which also helped contain the spread of grout within the immediate area of interest. A highly flowable cementitious grout was used, comprising pre-blended ash cement with a ratio of 10:1 of pulverised-fuel ash and ordinary Portland cement and a volumetric water/cement ratio not exceeding $0 \cdot 45: 1$. Where voiding was found to be substantial, a thicker grout mix with a sand:cement:bentonite ratio of $5: 1: 0 \cdot 2$ was used to reduce grout flowability and the subsequent risk of it flowing off site. Both grout mixes were designed to attain a minimum compressive strength of $0.84 \mathrm{~N} / \mathrm{mm}^{2}$ at $3 \mathrm{~d}$, thereafter increasing to 1.31 and $2.09 \mathrm{~N} / \mathrm{mm}^{2}$ at 7 and $90 \mathrm{~d}$, respectively. Based on the rock strength and overburden pressure at this location, an injection pressure of $200 \mathrm{kPa}$ was considered optimum.

A verification borehole at the centre of the foundation footprint confirmed that the grout had migrated laterally and filled the voids. In addition to the visual evidence of grout, a pressure test was also successful. To ensure that the stability of the railway was not compromised, monitoring of track settlement, horizontal displacement, voiding, cant and twist was undertaken before, during and after the remediation works.

The Coal Authority is liable to compensate Network Rail for any subsidence-related damage to the railway caused by coal mining that took place after 1 January 1940. Since coal mines along this route pre-dated this, the cost of void remediation was absorbed by the project.

\subsection{Real-time foundation monitoring}

Due to several foundations having been installed in high-risk areas prior to completion of the desk study and to verify the accuracy of the FE analyses, real-time monitoring of 27 foundations was implemented for a duration of 2 years. A couple of foundations in low-risk areas were also included for benchmarking.

The FlatMesh wireless monitoring system (Senceive, 2018) was used as it was proven to be accurate, reliable, robust to withstand challenges encountered in the railway environment, maintenance-free and with minimal site time requirements for its installation, operation and decommissioning. The system was delivered to site fully calibrated, tested and commissioned without the need for on-site cabling or snagging, thus considerably reducing the site installation time. Furthermore, due to the operational independence of each sensor, unforeseen damage or vandalism to one or more sensors would not disrupt the entire system. Owing to its low power consumption from batteries having a lifespan of 10-15 years, the system will easily allow uninterrupted monitoring for the required duration.

At node A, a triaxial tilt sensor attached to the top of the foundation by a secure magnetic plate (Figure 10(a)) recorded the angular rotation of the foundation in directions parallel 


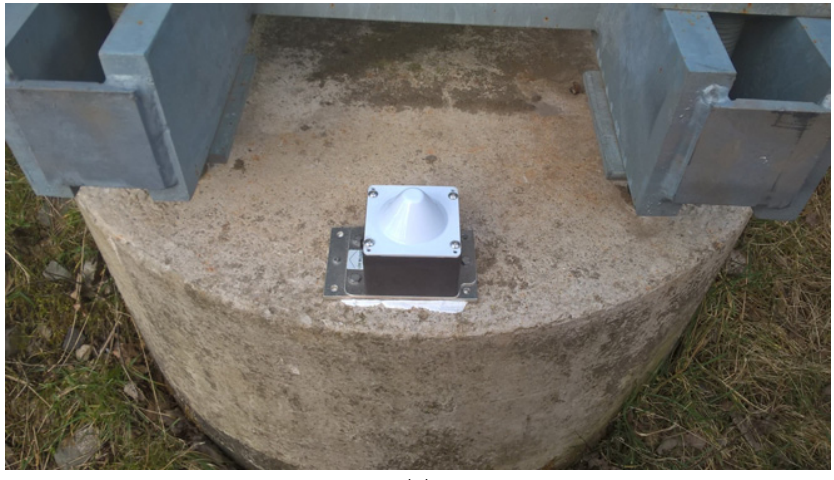

(a)

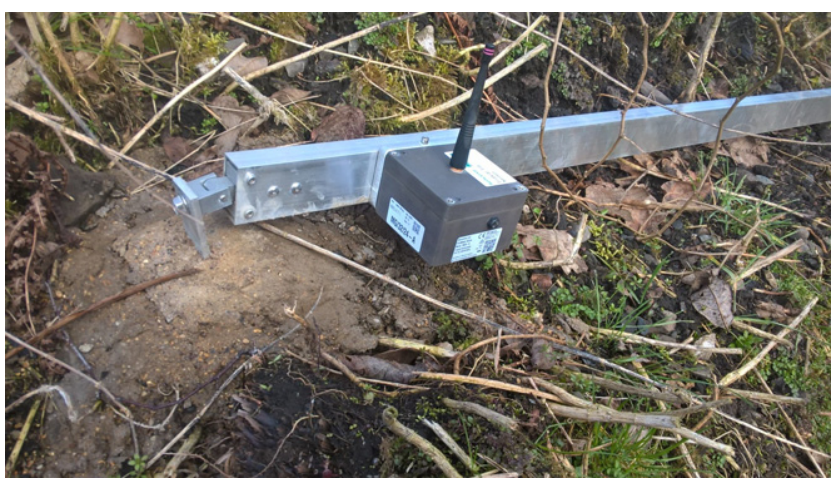

(c)

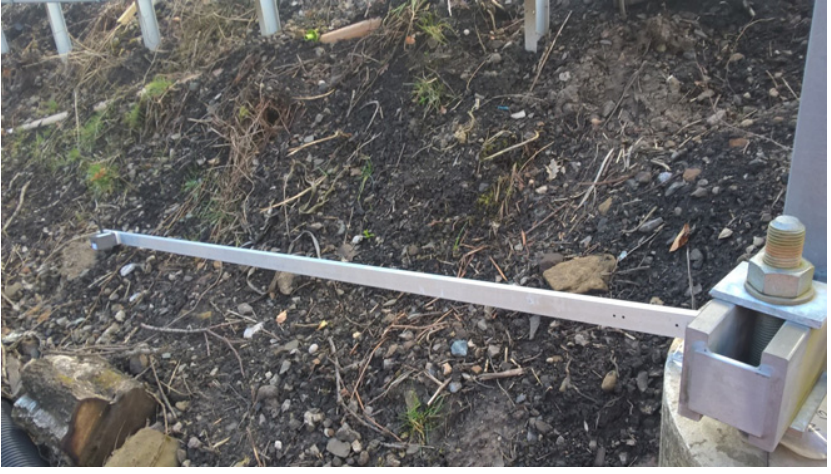

(b)

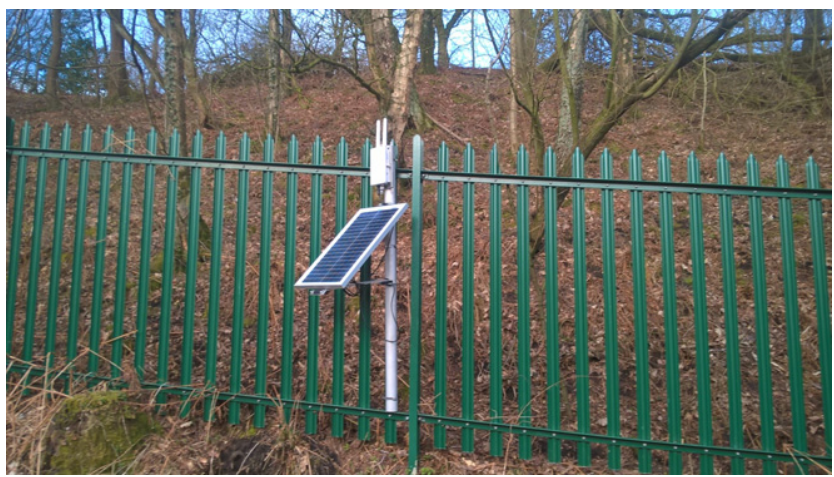

(d)

Figure 10. Real-time foundation monitoring system: (a) triaxial tilt node; (b) tilt beam; (c) triaxial tilt node at the end of a tilt beam; (d) 3 G gateway

and perpendicular to the track. At node B, a triaxial tilt sensor mounted at the end of a $3 \mathrm{~m}$ long tilt beam (Figures 10(b) and 10(c)) logged the settlement of the foundation. The sensors used are highly accurate with a repeatability of $\pm 0.0005^{\circ}$ $( \pm 0.0087 \mathrm{~mm} / \mathrm{m})$ and a resolution of $0.0001^{\circ}(0.00175 \mathrm{~mm} / \mathrm{m})$. Currently, data are recorded at $30 \mathrm{~min}$ intervals and communicated to a solar-powered $3 \mathrm{G}$ gateway (Figure 10(d)) from where it is transmitted over the internet to web-based data management software. However, the rate of reporting could easily be increased remotely if a particular foundation demonstrated excessive movement.

Delivered at a fixed contract fee of $£ 85000$, remote monitoring was very cost-effective when compared with undertaking additional intrusive ground investigations or conventional survey monitoring techniques. The contract was inclusive of levelling at periodic intervals to verify and baseline foundation settlement and to identify spurious data caused by sensor disturbance from OLE installation and an operational railway.

Based on interim monitoring data, the structures installed in locations perceived to be at a high risk of mining subsidence are not showing any signs of excessive tilt or settlement. For example, as illustrated in Figures 11(a) and 11(b), the actual across-track tilt and settlement of a bored pile supporting a twin-track cantilever in a high-risk mining area currently do not exceed $0.05^{\circ}$ and $1.2 \mathrm{~mm}$ respectively, which are less than the upper-bound values derived numerically and well within the corresponding serviceability thresholds of $0 \cdot 19^{\circ}$ and $25 \mathrm{~mm}$. The fluctuations in the recorded data are attributed to diurnal temperature variations (Figure 11(c)), In comparison, respective values of $0.014^{\circ}$ and $0.5 \mathrm{~mm}$ have been reported for the reference pile in a low-risk mining area (Figures 12(a) and 12(b)). Although there have been isolated occurrences of higher settlement values of $\sim 0 \cdot 8-0 \cdot 9 \mathrm{~mm}$ for this reference pile, they have been ignored as outliers. Since monitoring is ongoing, it will be interesting to observe long-term trends in foundation deformation, which will also assist in improving the FE models for future use.

\section{Conclusions}

Old shallow coal workings and mine entries can have an adverse effect on OLE infrastructure due to damage caused by ground subsidence. An innovative method, consisting of a thorough desk study, FE analysis, a precise, limited ground investigation and real-time foundation monitoring, was applied to NWEP phase 4 to investigate and mitigate these hazards. This led to the successful completion of foundation works 


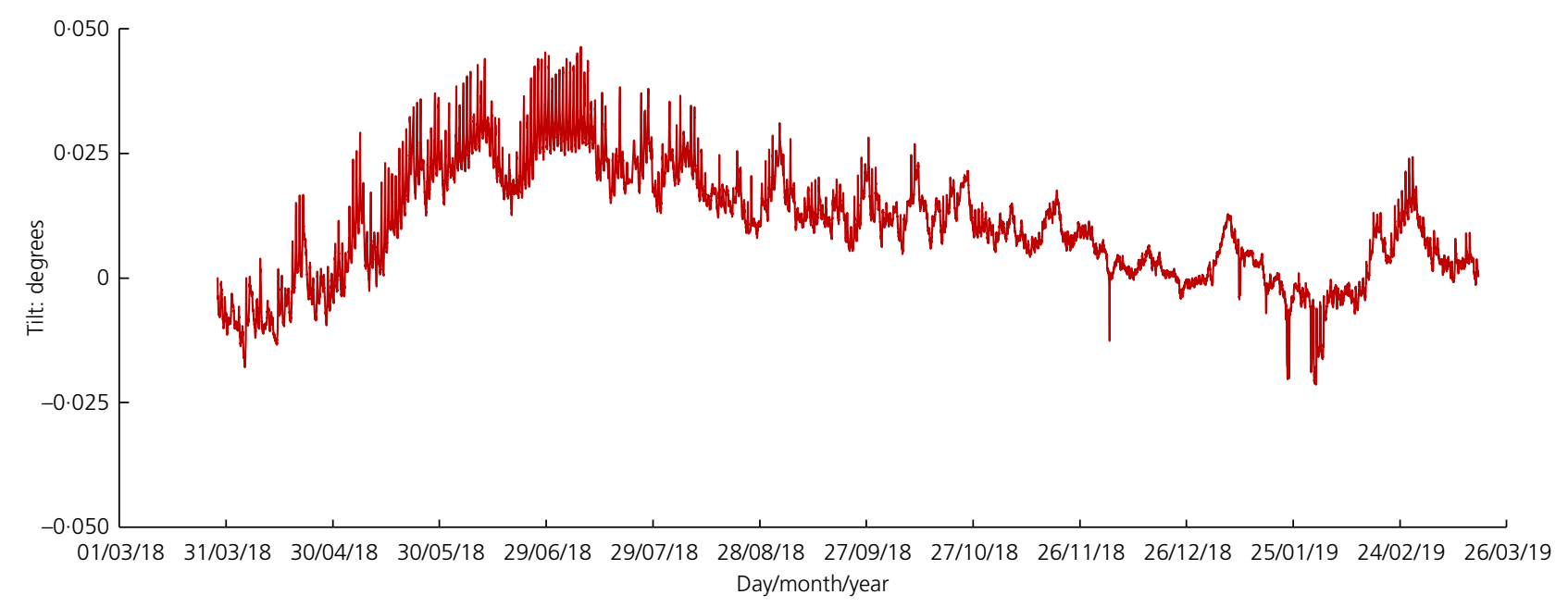

(a)

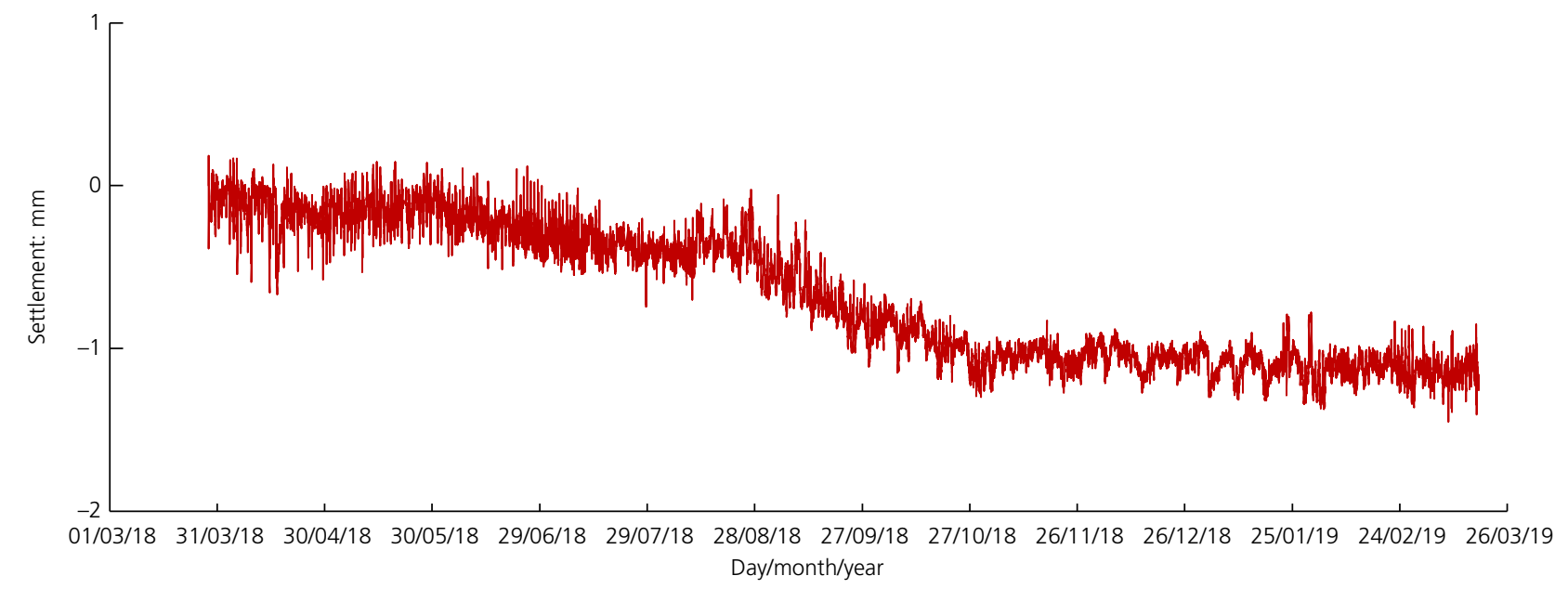

(b)

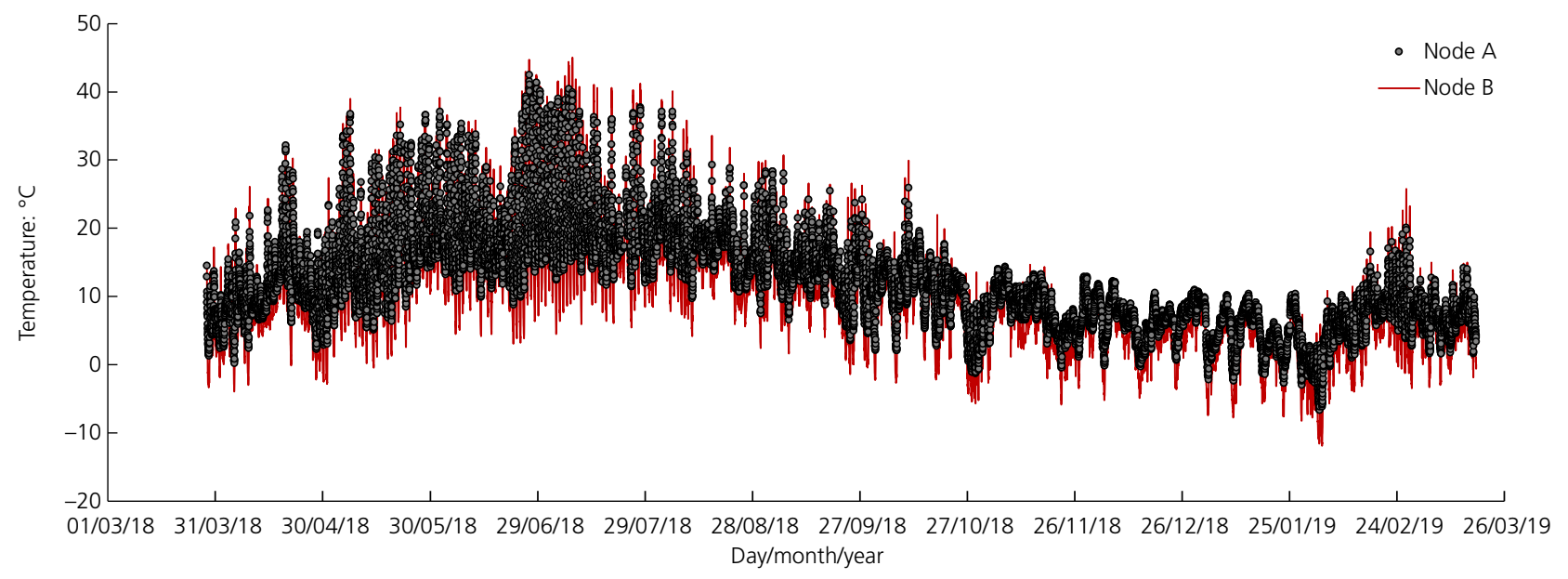

(c)

Figure 11. Monitoring results of a foundation in a high-risk mining area: (a) across-track tilt; (b) settlement; (c) diurnal temperature variation 


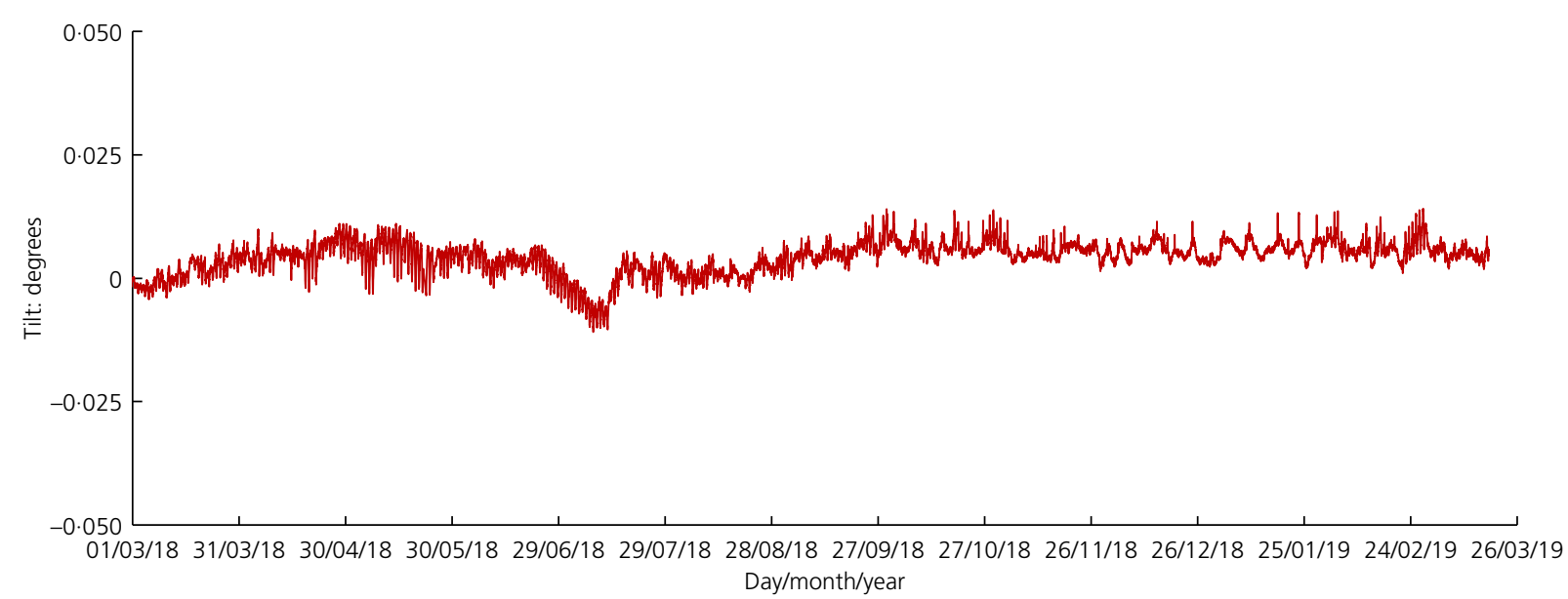

(a)

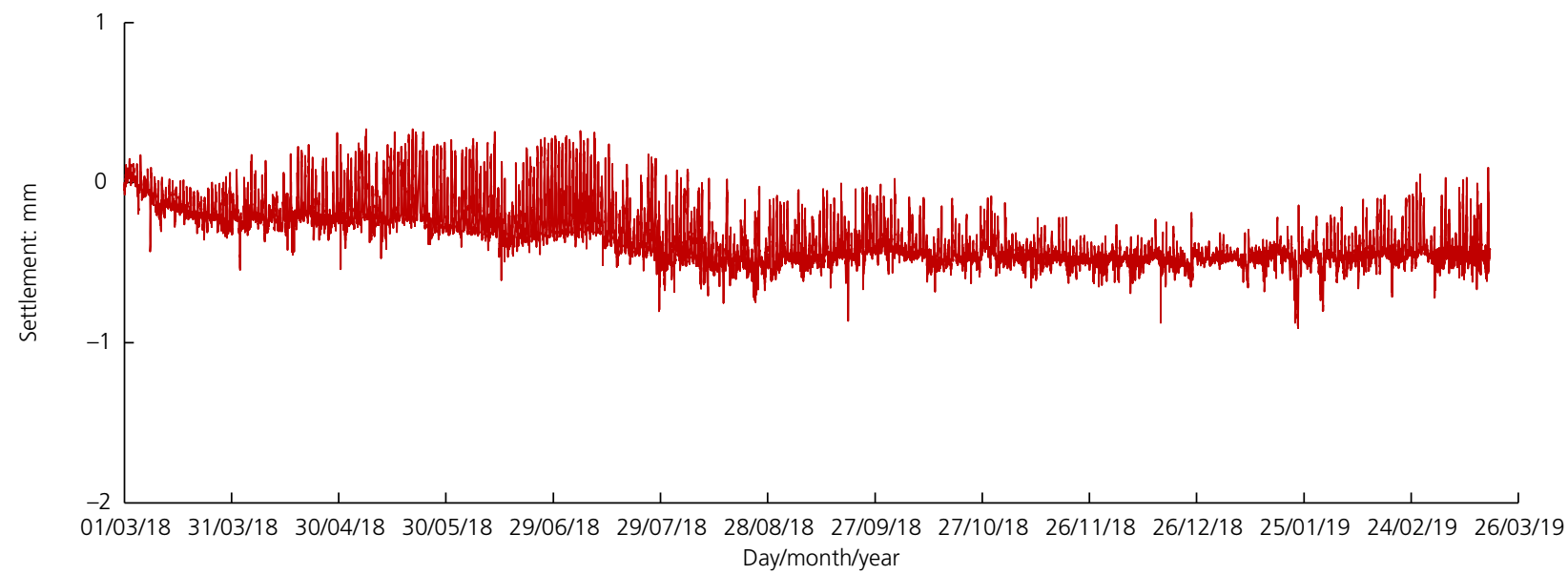

(b)

Figure 12. Monitoring results of a benchmark foundation in a low-risk mining area: (a) across-track tilt; (b) settlement

coupled with programme efficiencies and estimated cost savings of $£ 5$ million. However, as the mining investigation was undertaken in parallel with the design of OLE, some redesign was required. In future projects, it is recommended that the investigation be carried out at the feasibility phase to minimise design iterations and realise even greater efficiencies.

\section{Acknowledgement}

The author would like to acknowledge the assistance of Marc Williams in the compilation of the mining desk study.

\section{REFERENCES}

API (American Petroleum Institute) (1987) Recommended Practice for Planning, Designing and Constructing Fixed Offshore Platforms, 17th edn. API, Washington, DC, USA.

Bell FG (1978) Subsidence due to mining operations. In Foundation Engineering in Difficult Ground (Bell FG (ed.)). ButterworthHeinemann, London, UK, pp. 322-362.

Bell FG, Cripps JC, Culshaw MG and Lovell MA (1988) A review of ground movements due to civil and mining engineering operations.
In Engineering Geology of Underground Movements (Bell FG, Culshaw MG, Cripps JC and Lovell MA (eds)). Geological Society, London, UK, Engineering Geology Special Publication No. 5, pp. 3-32.

BGS (British Geological Survey) (2017) Geology of Britain Viewer. BGS, Nottingham, UK. See http://mapapps.bgs.ac. uk/geologyofbritain3d/index.html (accessed 02/09/2018).

Biot MA (1941) General theory of three-dimensional consolidation. Journal of Applied Physics 12(2): 155-164.

BSI (2004) BS EN 1997-1: Eurocode 7 - Geotechnical design. General rules. BSI, London, UK.

BSI (2007) BS EN 1997-2: Eurocode 7 - Geotechnical design. Ground investigation and testing. Incorporating corrigendum June 2010. BSI, London, UK.

BSI (2013) BS EN 50119+A1: Railway applications - fixed installations - electric traction overhead contact lines. BSI, London, UK.

BSI (2015) BS 5930: Code of practice for ground investigations. BSI, London, UK.

BSI (2016) BS EN ISO 22476-15: Geotechnical investigation and testing - field testing. Measuring while drilling. BSI, London, UK. Coal Authority (2017) Available Coal Authority Data Sets. Coal Authority, Mansfield, UK. See https://www.gov. 
uk/government/publications/available-coal-authority-data-sets (accessed 08/09/2018).

Carter P, Jarman D and Sneddon M (1981) Mining subsidence in Bathgate, a town study. In Proceedings of the 2nd International Conference on Ground Movements and Structures (Geddes JD (ed.)). Pentech Press, London, UK, pp. 101-124.

DSSC (Dassault Systèmes Simulia Corp.) (2017) Abaqus 2017. DSSC, Providence, RI, USA.

Healy PR and Head JM (1984) Construction over Abandoned Mine Workings. Construction Industry Research and Information Association, London, UK, CIRIA Report SP32.

Najjar Y and Zaman M (1994) Prediction of surface subsidence due to mining, using the finite element method. In Soil-Structure Interaction: Numerical Analysis and Modelling (Bull JW (ed.)) Spon Press, London, UK, pp. 395-421.

NAVFAC (Naval Facilities Engineering Command) (1986) DM 7.2: Foundations and Earth Structures. NAVFAC, Alexandria, VA, USA. Network Rail (2015) NR/L2/CIV/073: Design of overhead line structures. Network Rail, London, UK.

Ngamkhanong C and Kaewunruen S (2018) The effect of ground borne vibrations from high speed train on overhead line equipment (OHLE) structure considering soil-structure interaction. Science of the Total Environment 627: 934-941.

Ngamkhanong C, Kaewunruen S, Baniotopoulos C and Papaelias M (2017) Crossing phenomena in overhead line equipment (OHLE) structure in 3D space considering soil-structure interaction. In Proceedings of the World Multidisciplinary Civil EngineeringArchitecture-Urban Planning Symposium. IOP Publishing, Bristol, UK, IOP Conference Series: Materials Science and Engineering vol. 245, article 032047.
Piggott RJ and Eynon P (1978) Ground movements arising from the presence of shallow abandoned mine workings. In Proceedings of the 1st International Conference on Large Ground Movements and Structures (Geddes JD (ed.)). Pentech Press, London, UK, pp. 749-780.

Project Stakeholders (2017) Item 3.4: electrification in mining risk areas. Minutes of meeting between NWEP phase 4 and Walsall-to-Rugeley project stakeholders with network rail mining and route delivery teams 10 May 2017, Milton Keynes, UK.

Senceive (2018) FlatMesh. Senceive Ltd, London, UK. See http://www.senceive.com/products/flatmesh/ (accessed 28/08/2018).

Sepehri M, Apel DB and Szymanski J (2014) Full three-dimensional finite element analysis of the stress redistribution in mine structural pillar. Journal of Powder Metallurgy and Mining 3(1): article 119.

Sepehri M, Derek BA and Robert AH (2017) Prediction of mining-induced surface subsidence and ground movements at a Canadian diamond mine using an elastoplastic finite element model. International Journal of Rock Mechanics and Mining Sciences 100: 73-82.

UIC-ORE (International Union of Railways Office for Research and Experiments) (1957) Calculation of Catenary Masts and Foundations - Foundations Results of Tests, Conclusions and Practical Application. UIC-ORE, Utrecht, the Netherlands, Interim Report No. 1.

Walton G and Cobb AE (1984) Mining subsidence. In Ground Movements and their Effects on Structures (Attewell and Taylor RK (eds)). Surrey University Press, London, UK, pp. 216-242. 